Theme,

\section{A MAN IN THE COURT: EXPLORING THE THEME OF JUSTICE IN AND THEN THERE WERE NONE}

\author{
Sistiadinita \\ English Literature, STBA Pontianak \\ englishlitt.stba@gmail.com
}

justice, And

Then There

Were None,

Agatha

Christie, crime fiction

\begin{abstract}
Having to interact with crime fiction which presumably is considered as ephemeral literature, cannot be an excuse to dissolve the theme of justice inside the plots. Agatha Christie as the Mistress of Complication and Mystery, has written series of murder and mystery fiction since the beginning of twentieth century. And Then There Were None or entitled Ten Little Niggers, one of her masterpieces depicts Christie's unique disposition of turning perception from 'detective as criminal solver' into 'murderer as justice protector'. This paper seeks to analyze how justice is portrayed and challenged by looking at the characters created by Christie as well as making a more thorough analysis of the symbols and dialogues. The result of this paper portrays that the idea of justice, just like human beings, can be flawed or misinterpreted even by the so-called a man in the court.
\end{abstract}

Key words: theme, justice, And Then There Were None, Agatha Christie, crime fiction

\title{
INTRODUCTION
}

Reading literature is discerned as not only exploring the text as a whole, but also understanding the interpretative meaning behind the text. In exploring a literary text, especially fiction prose, the readers should concern with the aspects that build the story; the extrinsic aspect and the intrinsic aspect. The latter mentioned will follow the discussion of characters, setting, point of view, plot, symbols and theme. A theme is the idea, or the point of the book, an author's message to the readers. It is often complex yet crucial, sometimes difficult to grasp, and might be different for one person to another interpreting the theme of a same story. To varying degrees, most readers are likely to come out with an idea about the text they are having an experience with due to their subversive thoughts; the previous knowledge, personal experience and subjective expectation that may interfere. Otherwise, theme is an individual interpretation. Theme must logically come from the text, therefore, it should be supported with convincing descriptions or quotations from the text.

SPECTRAL

Jurnal Ilmiah STBA Vol.7 No.1

Januari 2021 ISSN 0216-3381

Many of the themes which are at the centre of detective and crime fiction are as old as human society and in this sense detective and crime fiction has a certain 
Theme, justice, And Then There Were None, Agatha Christie, crime fiction timelessness, which much of the other fiction does not have (Evans, 2009). The topic of justice is typical for a crime fiction. It captivates the readers' attention, since most of the stories about crime were highly developed around nineteenth and twentieth century and reflected the challenge of modernity, where women moved from doing domestic works to writing manuscripts. Evans (2009) further argues that detective fiction actively encourages revenge and punishment outside the processes of law and order. This view is actually generated as a result of people's fear of crime at the time.

This study is also built upon some relevant studies written by literary critics in the genre - in which discussing other themes. Take one study conducted by Lucie Neffova entitled Racial Attitude of the mid $20^{\text {th }}$ century Britain as reflected in Ten Little Niggers by Agatha Christie (2014). The discussion mainly revolves around historical development of race and racism, particularly in Britain. Further, the field of cultural studies is introduced as an approach to an analysis of literary works and also various theories about race and racism in literature, mainly in detective fiction, are presented. The application of the theory is shown on the analysis of specific situations and characters from the novel.

Another researcher who talks about Christie's crime fiction is Aneta Stepankova with her research English Society and Its Depiction in Selected Works by Agatha Christie (2013). This thesis aims to compare selected novels by Christie and the comprehensive historical studies. The research mainly answers the question on whether Christie mirrored English society faithfully.

This research takes some theoretical books into account about the causality of crime, the relation between crime and justice, and Christie's modernity. The book by Stephen Kern, A Cultural History of Causality (2006), in one of the chapters discusses about revenge and moral justice and how it has been a motive for murder from Greek tragedy to the modern age. This book also claims that a fixed criminal justice system cannot do justice to the complexity of the human mind in the modern world. The second is Imagination of Evil by Mary Evans (2009), who discusses the representation of modern world in twentieth century crime fiction written by women. The chapter 'Detecting the Modern' highlights the work of Christie and the social convention her work has offered.

According to Phillips and Huntley (2001), a theme is tied to every structural and dynamic element. It provides the various biases and perspectives necessary to convey the story's subject matter or meaning. Further, theme is considered a perspective 
Theme,

in which describing the relationship between what is being looked at and from where it is being seen. Theme is a relationship between plot and character (Phillips and Huntley). And Then There Were None introduced the readers to several themes, one of them is justice. The moral complexity in this book has brought two basic questions to be discussed; how is the theme of justice being portrayed in And Then There Were None, and can justice be flawed or misinterpreted by the character? By using formalism justice, And Then There Were None, Agatha Christie, crime fiction approach, the researcher tries to examine the form of the work as a whole, of each individual part of the text (the individual scenes and chapters), the characters, the settings, the tone, the point of view, the diction, and all other elements of the text which join to make it a single text. After analyzing each part, the researcher then describes how they work together to give meaning (theme) to the text. In Agatha Christie's And Then There Were None, the idea of justice is a major theme and is thoroughly explored through the context of the characters.

\section{METHODS}

The primary data for this study was taken from Agatha Christie's And Then There Were None. The description of the characters and dialogues became the focus in explaining the theme being analyzed by the researcher, while other secondary data are taken from some theoretical books and academic journals. Since the researcher applies the formalism approach in which seeing the text as a self- contained object, the analysis was made only through the story's intrinsic element to determine which dialogues or descriptions that represent the idea of justice and how it is interpreted. The aspects being analyzed include symbols, setting, characters and the point of view.

\section{FINDINGS AND DISCUSSION}

\section{Findings}

The story began and ended with a letter. And Then There Were None portrays seven men and three women with various occupations and characters; a confident doctor (George Armstrong), a wary school mistress hired as secretary (Vera Claythorne), a couple of obedient servants (Mr. And Mrs. Rogers), a bold detective (Henry Blore), a scrupulous judge (Lawrence Wargrave), an ardent traveller (Philip Lombard), an old general (General Macarthur), a rebelious bachelor (Anthony Marston), and a middle- 
Theme,

justice, And Then There Were None, Agatha Christie, crime fiction aged woman with high piety (Emily Brent) who were invited to a luxurious island with full of hints and interesting rumours by someone with vague identity. Nevertheless, all the invited people discerned this as an intriguing request, out of the fact that they were assembled to be killed for committing past criminals. The story started when a retired judge, Mr. Lawrence Wargrave, received a letter from his correspondent stated he had arranged a small reunion in Negroid island, Sticklehaven, Devon and wanted him to come around. The similar letters were also received by three other people (Brent, Macarthur, and Marston) who wished to meet their old friends. Other six upcoming victims, predominantly, accepted to work under Mr. U.N. Owen's authority for a week. At the end, a letter in a bottle illustrated the chronological ways of a murderer killing all- ten suspects (which he thinks as those who slipped off of jurisdiction) and his proud confession to pay off his sinister vengeance by killing himself. What makes this story strikingly surprising, all letters were written by the same person, the culprit who wrote the letter at the end was the one who read the letter at the very beginning of narrative.

To begin with, let us not focus on why or how they were killed. Otherwise, look toward the reasons why these professionals were eager to fulfill the invitation from the mysterious man. From the story, it was clearly depicted that the guests found suspicion in their letters regarding the identity of the sender. Even though the letters came from (what they considered) their old friends, still the signature was found ambiguous. Just like what Mrs. Brent thought about her letter. Emily Brent was a religious woman who read her Bible everyday. She considered worldly excitement as useless intoxication that she always tried to avoid. As a result, she was delightful to get the letter from a nice old- fashioned type of person she met some years ago at a Guest House, however, she could not remember her well.

'Mentally she reread the letter which she had already read so many times. What was the name? The signature was rather difficult to read, Emily Brent thought impatiently: "So many people write their signatures quite illegibly'(Christie, p.195).

The similar thing occured to General Macarthur who was vacillating about the existence of this Owen. His doubt was defeated by banal thoughts convincing himself that it was just a small reunion in a small island. He was always fascinated to chatting about old times with good old fellows, a moment which must not be overlooked. This 
Theme,

moment, an enjoyment of fulfilling emotional desire in maintaining friendship and old memories was treasured by most oldsters.

"He hadn't got it clear who this fellow Owen was. A friend of Spoof Leggard's, apparently- and of Johny Dyer's. 'One or two of your old cronies are comingwould like to have a talk over old times", (Christie, p.196).

justice, And

Then There

Were None,

Agatha

Christie,

crime fiction

In spite of all the danger possibility, most of guests, like Emily Brent and Macarthur, denied facts considering the place where they were heading to and repayment of attending the invitation. Negroid island was described as 'giving a unique sense of allurement' with its mystery and popularity. Got an offer to visit the island without any expenses, gave more interest for those who were economically disadvantaged. Philip Lombard was a mercenary hired due to his remarkable reputation in dealing with high impediment. Mr. U.N. Owen offered him a hundred guineas to travel to Sticklehaven, Devon, for doing what he surmised as risky and illegal. Without any further thought, he decided to come. He thought what he would do was trifling, the most important thing was to enjoy himself with the money, in an island.

He had said it in a casual way as though a hundred guineas was nothing to him. A hundred guineas when he was literally down to his last square meal! He had fancied, though, that the little Jew had not been deceived - that was the damnable part about Jews, you couldn't deceive them about money- they knew!

(Christie, p.194)

Vera Claythorne introduced herself as a hired secretary to Mrs. Roger, the house-servant, soon after she arrived in Negroid island. Vera recently lost passion on what she was doing after a tragic incident toward Cyril, one of her upbringings. Cyril was found dead- drowning when he was playing out of the sea with her. She inwardly felt guilty after his death. It haunted her not because of the death, but the fact that her boyfriend, Hugo, consequently left her. Hugo believed she did it for heartless intention, which was sadly true. In the mean time, her temporary job in Negroid island probably could kill her fear and helped her moving on. Possessing unrevealed indictments triggered her to look for little sort of enjoyment out of her routines. Vera Claythorne when she was on the train to Sticklehaven,

It would be nice to get to the sea! Really a great piece of luck getting this job. When you wanted a holiday post it nearly always meant looking after a swarm of children - secretarial holiday posts were much more difficult to get. Even the agency hadn't held out much hope.

(Christie, p.192) 
Theme, justice, And Then There Were None, Agatha Christie, crime fiction
The glorious feeling she had, gave obvious reflection to the recognizable pattern of human character; interest in money and excitement of leaving the bitter past.

When someone rich yet mysterious proposed a promising job, he placed the 'deviant' side to obey the 'authoritative' character. In this case, power became the basic element which controlled other parties to involve in its playful authority. The people were chosen to come to the island for not getting equal punishments to their past criminal actions. This was a catalyst for the judge to take actionable pieces of justice. He believed that money and enjoyment were helpful ingredients to grasp anyone's attention. This prediction guided the main actor in undergoing his impish intention. Besides, the judge had observed all his victims circumstances; both financially and mentally. By taking advantage from hot issues about Negroid island which spread over the newspapers had fortified reasons for the guests to come. His wealth and understanding toward human nature had undeniable links to the success of his invitation.

The suspense in Negroid island began with a voice recording playing to list each visitor's past crime.

'You are charged with the following indictments: Edward George Armstrong, that you did upon the 14th day of March, 1925, cause the death of Louisa Mary Clees. Emily Caroline Brent, that upon the 5th November, 1931, you were responsible for the death of Beatrice Taylor. William Henry Blore, that you brought about the death of James Stephen Landor on October 10th, 1928. Vera Elizabeth Claythorne, that on the 11th day of August, 1935, you killed Cyril Ogilvie Hamilton. Philip Lombard, that upon a date in February, 1932, you were guilty of the death of twenty one men, members of an East African tribe. John Gordon Macarthur, that on the 4th of January, 1917, you deliberately sent your wife's lover, Arthur Richmond, to his death. Anthony James Marston, that upon the 14th day of November last, you were guilty of the murder of John and Lucy Combes. Thomas Rogers and Ethel Rogers, that on the 6th of May, 1929, you brought about the death of Jennifer Brady. Lawrence John Wargrave, that upon the 10th day of June, 1930, you were guilty of the murder of Edward Seton. Prisoners at the bar, have you anything to say in your defence?' (Christie, p.216 $-217)$

Justice Wargrave, with his power from a court enabled him to take over the situation, convincing others that blaming him was a total mistake. He exhibited powerful plots when one by one the victim fell to death, even himself. In addition, he could wash away everyone's suspicion and drew their conclusion to an idea of 'A judge must be clean and innocent'. Raymond Williams, who found the notion of 'Cultural Materialism' pointed 
Theme,

out, 'Cultural materialism concurs in the basic analysis of the operations of power.' (Introducing Literary Studies, p.588). To the lower social class group, all the indictments are considered judgmental especially if those were not proven correct. "It was The Voice - that awful voice - like a judgement -" said Mrs Rogers, one of the servants in the house.

Christie created this work with third person perspective which enable readers to justice, And Then There Were None, Agatha Christie, crime fiction look at each character's point of view, except for the criminal mastermind's plan which was revealed unblemished at the end of the story. If we divide the guests into two groups of people; Lombard's group (Claythorne, Blore, Armstrong, Mr. and Mrs. Rogers) who came for promising job and Brent's group (Macarthur and Marston) who came to meet their old friends, two logical patterns were drawn in attending the culprit's invitation; material urgency and emotional impulsion. The former group saw Mr. Owen as a wealthy man and to work under his power was a noteworthy experience. Moreover, the offer positively correlated with their ability and financial need. Meanwhile, the latter group looked at this invitation as an escape from their solitary moments they faced at a time, except for Antony Marston. As the youngest person in this trip, he was not lonely at all. Marston's charming figure supported him to be a remorseless chap. He saw his life as an enjoyable journey and no one should block his way.

Wargrave's overwhelming desire to instill justice, therefore, leads him to deviate from the norm and punish those who he deemed guilty through his sick and gruesome way. He presents himself as the fighter of injustice and entrusts himself with the role of punishing those who had escaped the consequences of the law. The traditional sense of justice, however, remains the same. Wargrave, in his conventional role as a judge, enforces justice by sentencing the guilty to prison or execution in the court room. His confession in a bottle confirmed this.

But side by side with this went a contradictory trait - a strong sense of justice. It is abhorrent to me that an innocent person or creature should suffer or die by any act of mine. I have always felt strongly that right should prevail.

It may be understood - I think a psychologist would understand - that with my mental makeup being what it was, adopted the law as a profession. The legal profession satisfied nearly all my instincts. (Christie, p.350)

Similarly, Indian island serves as a court room for Wargrave, and the ten "Indians" are the defendants who are waiting for Wargrave's pronouncement of their death sentence. 
Theme, justice, And Then There Were None, Agatha Christie, crime fiction

It can also be argued that the murders of some of the characters are unjustified because their apparent "crimes" are petty and insignificant, thus the punishment inflicted on those characters were undeservingly received.

The theme of justice in the novel is developed through various symbols and motifs. One of the symbols is the mark on the forehead of judge Wargrave. This mark, which looked like a fire shot, is an example of someone who is guilty in murder, as well as the universality of Wargrave's crime.

"I shall be found, laid neatly on my bed, shot through the forehead in accordance with the record kept by my fellow victims. Times of death cannot be stated with any accuracy by the times our bodies are examined. When the sea goes down, there will come from the mainland boats and men. And they will find ten dead bodies and an unsolved problem on Indian Island. Signed - Lawrence Wargrave. (Christie, p. 358)

The storm is another powerful symbol used in the novel. In the beginning of the story, the mentioning of the squall beforehand by the old man in the train serves as the first sign of the forthcoming retribution: "Watch and pray," he [the old man] said. "Watch and pray. The day of judgment is at hand." (Christie, p.200). The motif of retribution and punishment for sin manifests itself in the book:

"In her bedroom, Emily Brent, dressed in black silk ready for dinner, was reading her Bible. Her lips moved as she followed the words: "The heathen are sunk down in the pit that they made: in the net which they hid is their own foot taken. The Lord is known by the judgment which he executed: the wicked is snared in the work of his own hands (Christie, p.214).

In other words, the character also inwardly realized of her own action, yet tried to embrace her own guilt and claim it as an innocence.

The judge used his power to invite his upcoming victims by observing each of their character. This idea was in line with Harriot in his Brief and True Report of the New Found Land of Virginia (1588), 'Power continually defines itself through whatever threatens it' (Introducing Literary Studies p. 587). For Wargrave, gathering nine people and killing them one by one was his sort of enjoyment. He also wanted to end his life by leaving a remarkable story behind. He thought of life as a boring playground and he wanted to create his own by bringing the old nursery rhyme Ten Little Indian Poems into life. Wargrave was an embodiment of 'a man in the court', whose power was used to determine what he called as justice - a misinterpretation, that leads to other more cruel wrongdoings and could break the existing morality. 
And Then There Were None is basically a simple story. Ten strangers are invited to a weekend on an island off the coast of Devon. Their host fails to appear and a series of deaths among their fellow-guests make them realize that one of them is a killer following the unique nursery rhyme that hangs in each bedroom. Each guest dies in a manner related to the appropriate verse from the nursery rhyme (Osborne, 1983). In the end a murderer is revealed and a plot so clever that makes most readers bewildered.

Definition of crime is never simple to be discussed. The complication in defining crime involves changing morality and cultural differences as well as the fact that crime is not at a standstill. Crime changes and evolves over time (Henry \& Lanier, 1998). Today's criminal activity is tomorrow's deviance or prank. And Then There Were None can be one of the resources in depicting the changes in crime over time.

At the beginning of the novel, it seems that all the criminal actions accused by the judge as serious variations of law. Dr. Armstrong caused the death of Louisa Mary Clees ; Emily Brent is responsible for the death of Beatrice Taylor; William Blore brought about the death of James Landor; Vera Claythorne killed Cyril Hamilton; Philip Lombard is guilty of the death of twenty-one men; General Macarthur deliberately sent [his] wife's lover to his death"; Anthony Marston is guilty of the murder of John and Lucy Combes; Thomas and Ethel Rogers brought about the death of Jennifer Brady; and Judge Wargrave is guilty of the murder of Edward Seton (Christie, 216 - 217).

Behind all these simple accusations, there was a more trifling secret. As time passed by in the novel, each character one by one admitted their own deeds. Wargrave became the first person to admit that he was involved in the homicide, pointed an accusation to Edward Seton making him faced his death penalty. At that time Wargrave was involved in the jurisdiction process. Vera Claythorne also admitted of being involved in Cyril Hamilton's case. Claythorne served as a governess and she carelessly left Cyril drowned in the ocean. General Macarthur was revealed to have been guilty over the death of one of his soldiers since he found out that soldier had an affair with his wife. A similar problem actually happened to Philip Lombard. In order to save himself, he abandoned a group of natives in the jungle to face their death. He believed he was not guilty because he could not be responsible for that. Anthony Marston claimed that it was an accident when he hit two children with his car, resulting him in losing his license. Mr. and Mrs. Rogers were accused of losing the live of their previous rich employer, assuming they would get the advantage from that. The next suspect, William Blore, admitted that he had sent a defendant who later 
Theme, justice, And Then There Were None, Agatha Christie, crime fiction

died in jail because of his false accusation. Dr. Armstrong was actually drunk when he operated a patient. Armstrong's unstable condition caused the patient to die under his surgery. The last, Emily Brent, the most pious of them all, was revealed to kick out one of her service girl who was in her pregnancy. The girl then committed suicide after giving up her destiny.

060 Justice Wargrave is the administrator of the law and the murder on Indian island are merely prosecutions where the guilty are brought down in the name of the law and as a result, enforcing justice. As it was mentioned before, the administration of justice is a common theme in many murder mysteries when an individual commits a crime, and it is only a matter of finding that individual and punishing them through the law. Agatha Christie, however, departs from this formulaic approach by introducing the characters to a so- called justice protector which is not punishable through any normal means. If all the crime committed by the characters cannot be prosecuted under the normal proceedings of law, can Wargrave as the judge be considered innocent of any wrongdoings even though his actions in question are morally unjustified? Trapped on an island and distanced from society, the characters in the story are forced to come to terms with their past actions as they wait for their death sentence.

Discussion of these accusations particularly reveals that most of them carry no legal penalty today. This of course does not mean that the actions are not deviant. It means that there is a difficulty in defining two terms; crime and deviance (Pruitt, 2017). Even in Christie's time, most of these actions would not be criminal, although they will still be considered as immoral. That also means that criminal justice definition should be followed with the understanding on the role of morality. Discussing how Christie portrays these crimes versus how they are seen by the criminal justice system today allows for comparison across time.

\section{CONCLUSION}

In And Then There Were None, Agatha Christie presents justice as an unclear concept. The new discussion may arise to further questions like who actually deserve the punishment and how much punishment each of the character deserves. The criminal who is also a justice fanatic has eventually committed a more serious criminal actions than all of the characters ever did before. It was to say that, to Christie, just like 
Theme,

common human beings, justice can sometimes be misunderstood and inherently flawed.

Agatha Christie shows that there is a danger in a simple term as justice. Justice can be interpreted different by other viewpoints, in other word, enigmatic. There is no perfect way to punish every criminal who has done deviant acts, but breaking from the existing law, in one way or another, is a serious matter, not to say precarious.

justice, And

Then There

Were None, Agatha Christie, crime fiction

\section{REFERENCES}

\section{Primary Text}

Christie, A. (1977). And Then There Were None. In Masterpieces of murder (The Murder of Roger Ackroyd/And Then There Were None/Witness for the Prosecution/Death on the Nile (pp. 189-359). story, Dodd, Mead.

\section{$\underline{\text { Secondary Texts }}$}

Bookworm. (2012, August 20). Literary Justice. Retrieved January 30, 2021, from https://literacle.com/literary-justice/

Bradford, R. (1996). In Introducing literary studies (pp. 568-592). essay, Prentice Hall/Harvester Wheatsheaf.

Evans, M. (2011). Imagination of evil: Detective fiction and the modern world. New York: Continuum.

Henry, S., \& Lanier, M. M. (1998). The prism of crime: Arguments for an integrated definition of crime. Justice Quarterly, 15(4), 609-627. doi:10.1080/07418829800093921

Johnson, B. (2017, February 26). The Application of Justice - And Then There Were None: FreebookSummary. Study Guides and Book Summaries. https://freebooksummary.com/the-application-of-justice-and-then-there-werenone-45253.

Kabashima, H. (n.d.). The Idea of Justice in Literature. Retrieved January 30, 2021, from https://www.springer.com/gp/book/9783658219956

Keating, H. R. F. (1977). Agatha Christie: first lady of crime. Weidenfeld and Nicolson.

Kern, S. (2006). A cultural history of causality science, murder novels, and systems of thought. Princeton: Princeton Univ. Pr.

Knight, S. (2004). Crime fiction, 1800-2000 detection, death, diversity. Palgrave Macmillan.

Light, A. (2013). Forever england: femininity, literature and conservatism between the wars. Routledge.

Murphy, B. (2008). The encyclopedia of murder and mystery. New York: Palgrave for St. Martin's Minotaur.

Neffová, L. (2014). Racial attitudes of the mid 20th century Britain as reflected in "Ten Little Niggers" by Agatha Christie (Unpublished master's thesis, 2014).

Osborne, C. (1983). The life and crimes of Agatha Christie. New York: Holt, Rinehart and Winston. 
Theme,

justice, And Phillips, M. A., \& Huntley, C. (2004). Dramatica: A new theory of story. Glendale, CA: Then There Write Brothers Press.

Were None, Plain, G. (2010). Twentieth-century crime fiction: Gender, sexuality and the body. Agatha Edinburgh: Edinburgh University Press.

Christie, $\quad$ Pruitt, W. R. (2017). Using And then there were none to teach crime. Academic

crime fiction Exchange Quarterly, 21(4). Retrieved January 31, 2021, from http://rapidintellect.com/AEQweb/ec5839j7.pdf

062 Writing Formalist Literary Analysis. (n.d.). Retrieved January 30, 2021, from https://www2.bellevuecollege.edu/artshum/materials/engl/silano/fall2005/101lsb/f ormalistlitanalyassgn.htm

Štěpánková, A. (2013). English Society and Its Depiction in Selected Works by Agatha Christie Aneta Štépánková Bachelor thesis 2013 (Unpublished master's thesis). University of Pardubice. 